\title{
Apparent digestibility of nutrients and energy of conventional ingredients for the silver mojarra, Diapterus rhombeus
}

\section{Digestibilidade aparente de nutrientes e energia de ingredientes convencionais para carapeba, Diapterus rhombeus}

\author{
Francisco Oliveira de Magalhães Júnior ${ }^{1}$; Ricardo Henrique Bastos de Souza ${ }^{2}$; \\ Érica Bevitório Passinato ${ }^{3}$; Filipe dos Santos Cipriano ${ }^{4}$; Kauana Santos Lima; \\ William Cristiane Telles Tonini ${ }^{6}$, Luís Gustavo Tavares Braga ${ }^{7^{*}}$
}

\begin{abstract}
Knowledge on the nutritional value of feed ingredient is an important step in the formulation of diets in order to maximize animal productivity. Thus a study was conducted to determine the apparent digestibility coefficients (ADC) of dry matter (ADCDM), crude protein (ADCCP), gross energy (ADCGE) and amino acids (ADCAA) of conventional feed ingredients for juvenile silver mojarra (13.0 $\pm 3.23 \mathrm{~g}$ ). The study was conducted in the laboratory for nutrition and feeding of fish (AQUANUT), using 80 silver mojarra collected in nature, which were kept in digestibility aquaria for a period of 21 days. The following ingredients were evaluated: fish meal, soybean meal, corn meal, corn gluten meal, rice bran, wheat bran and starch, which substituted $30 \%$ of a reference pelletized diet with $325.00 \mathrm{~g} \mathrm{~kg}^{-1}$ crude protein and 3,692 $\mathrm{Kcal} \mathrm{kg}^{-1}$ gross energy. Additionally $1.0 \mathrm{~g} \mathrm{~kg}^{-1}$ chrome oxide was added to each diet as a marker. The excreta were obtained using three repetitions for each tested ingredient, which were dried for further analyses. The soybean meal showed the best ADCDM value (67.45\%), followed by the other ingredients. There was no significant difference between the soybean meal $(95.16 \%)$, fish meal $(92.97 \%)$ and the corn meal $(91.90 \%)$ for the best ADCCP coefficients. The ADCGE for soybean meal and maize meal were $65.23 \%$ and $60.31 \%$, respectively, followed by fish meal $(51.85 \%)$. The results demonstrate that silver mojarra can digest animal protein as well as that of vegetal origin. Silver mojarra can also efficiently digest and absorb some of the main amino acids of fish, such as lysine, methionine and threonine, from the same studied ingredients.
\end{abstract}

Key words: Acará-peba. Amino acid. Mariculture. Nutritional value.

\section{Resumo}

O conhecimento do valor nutritivo de alimentos é um passo importante na formulação de dietas para maximizar a produtividade animal. Foi realizado um estudo para determinar os coeficientes de

\footnotetext{
${ }^{1}$ Discente do Curso de Doutorado no Programa de Pós-Graduação em Ciência Animal, Universidade Estadual de Santa Cruz, UESC, Ilhéus, BA, Brasil. E-mail: jr.oliveira@zootecnista.com.br

2 Prof., Universidade Federal de Rondônia, UNIR, Presidente Médici, RO, Brasil. E-mail: rick.pesca@hotmail.com

${ }^{3}$ M.e em Ciência Animal, UESC, Ilhéus, BA, Brasil. E-mail: erica.passinato@hotmail.com

${ }^{4}$ Discente do Curso de Doutorado no Programa de Pós-Graduação em Zootecnia, Universidade Federal de Minas Gerais, UFMG, Belo Horizonte, MG, Brasil. E-mail: filipecipriano@hotmail.com

5 Discente do Curso de Doutorado no Programa de Pós-Graduação em Zootecnia, Universidade Federal da Bahia, UFBA, Salvador, BA, Brasil. E-mail: kslima@ymail.com

${ }^{6}$ Prof. Dr., Dept ${ }^{\circ}$ de Eng ${ }^{\mathrm{a}}$ de Pesca, Universidade do Estado da Bahia, UNEB, Xique-Xique, BA, Brasil. E-mail: willcttonini@, gmail.com

7 Prof. Dr., Programa de Pós-Graduação em Ciência Animal, UESC, Ilhéus, BA, Brasil. E-mail: lgtbraga@gmail.com

* Author for correspondence
} 
digestibilidade aparente (CDA) da matéria seca (CDAMS), da proteína bruta (CDAPB), da energia bruta (CDAEB) e dos aminoácidos (CDAAA) de ingredientes convencionais para juvenis de carapeba $(13 \pm 3,23 \mathrm{~g})$. O estudo foi realizado no Laboratório de Nutrição e Alimentação de Peixes (AQUANUT), utilizando 80 exemplares de carapeba, coletados na natureza, que foram mantidos em aquários de digestibilidade no período de 21 dias. Foram avaliados os seguintes ingredientes: farinha de peixe, farelo de soja, fubá de milho, farelo de glúten de milho, farelo de arroz, farelo de trigo e amido, que substituíram 30\% de uma dieta referência peletizada com 325,00 $\mathrm{g} \mathrm{kg}^{-1}$ de proteína bruta e 3,692 Kcal $\mathrm{kg}^{-1}$ de energia bruta, utilizando $1,0 \mathrm{~g} \mathrm{~kg}^{-1}$ óxido de cromo como marcador. As excretas foram obtidas utilizando três repetições para cada ingrediente testado, e após a secagem foram realizadas as análises laboratoriais. O farelo de soja apresentou o melhor resultado para o CDAMS $(67,45 \%)$ seguido pelos demais ingredientes. Para o CDAPB não houve diferença significativa entre o farelo de soja $(95,16 \%)$, a farinha de peixe $(92,97 \%)$ e o fubá de milho $(91,90 \%)$ que apresentaram os melhores coeficientes de digestibilidade. Em relação ao CDAEB os resultados do farelo de soja e fubá de milho foram 65,23 e $60,31 \%$, respectivamente, seguidos pela farinha de peixe $(51,85 \%)$. A carapeba aproveita alimentos tanto de origem animal quanto de origem vegetal, evidenciando também eficiência em absorver aminoácidos como a lisina, metionina e treonina, para os mesmos ingredientes estudados.

Palavras-chave: Acará-peba. Aminoácido. Valor nutricional. Maricultura.

\section{Introduction}

The silver mojarra, Diapterus rhombeus, is an omnivorous fish, which is well-adapted to environments with different salinities characteristics that are favorable for fish farming. Studies with silver mojarra have been conducted on its biology (ETCHEVERS, 1978; CHAVES; OTTO, 1998; SILVA et al., 2011) and distribution aspects (ARAÚJO; SANTOS, 1999; AYALAPEREZ et al., 2001; COSTA et al., 2012). However, the digestibility of ingredients has not been the subject of research and this is a major step for the development of an efficient diet to promote a better nutritional status for the animals.

A major challenge in fish farming is to obtain high productivity, with minimal waste excreted into the environment. This is particularly applied to the excretion of nitrogen $(\mathrm{N})$ and phosphorus (P), which limit the primary production of algae and can cause eutrophication in fish production systems that rely on a balanced diet (FURUYA et al., 2005; CYRINO et al., 2010). Thus, the availability of nutrients for the fish should be determined in terms of digestibility, which is the fraction of the nutrients in the food ingredients that is not excreted (GODDARD; MCLEAN, 2001; NRC, 2011).
The determination of the coefficient of food digestibility is important to assess the nutritional value of ingredients to be used in the formulation of fish diets. This determination is based on the analysis of the ability to digest and absorb nutrients from the ingredients ingested by fish, and depends on the conditions and methods applied in digestibility experiments (DE SILVA, 1989; BUREAU et al., 2002). Therefore, the objective of this study was to evaluate the apparent digestibility of protein and energy sources in juvenile silver mojarra.

\section{Material and Method}

\section{Fishes and infrastructure}

The juvenile silver mojarra were obtained in a natural environment in the estuary in the region of Ituberá-BA (13\%43'13.9'S and 39 $07^{\circ} 46.7^{\prime}$ 'W), with the support of local fishermen, using a beach trawl with the dimensions of $50 \times 2 \mathrm{~m}$ and a mesh with 12-mm internodes, dip nets, boat and vessel support. Approval for the fish catching was granted by the Brazilian Institute of Environment and Renewable Natural Resources (IBAMA), through the Authorization and Information on Biodiversity System (SISBIO) under process $n^{\circ}$. 39868-1. The 
fish were transferred to an adaptation experimental laboratory, temporarily established in the city of Ituberá, where they were kept in glass-fiber boxes $(310$ L) with constant aeration and a biofilter for constrained adaptation to the environment and feed management, consisting of four daily feeds with pelleted feed (30\% crude protein) offered until apparent satiety. Fifteen days later, the fish were transferred to the Laboratory of Food and Fish Nutrition (AQUANUT) of the State University of Santa Cruz, Ilhéus, Bahia, Brazil (14\%47'20'S and $\left.39^{\circ} 02^{\prime} 58^{\prime \prime} \mathrm{W}\right)$, in shipping boxes (500 L) equipped with oxygenation system. The fish were submitted to a second adjustment period of two weeks to the laboratory facilities, using the same food management previously adopted.

For the digestibility trial, which lasted 21 days, 80 specimens of silver mojarra $(13 \pm 3.23 \mathrm{~g})$ were used, which were kept in eight digestibility aquaria (10 fish/aquarium) with conical shapes (200 L) that were equipped with an aeration and biofilter system. At the bottom of the aquaria, 200-mL plastic collectors were installed and were kept submerged in water and ice to decrease the microbial activity/ degradation during feces collection.

Water quality in terms of temperature, $\mathrm{pH}$, dissolved oxygen and salinity was measured daily at 9:00, using a multiparameter YSI Professional Plus device, and showed mean values of $25.75^{\circ} \mathrm{C}$ $\pm 0.8 ; 7.49 \pm 0.3 ; 8.25 \pm 1.2 \mathrm{mg} \mathrm{L}^{-1} ; 21.9 \pm 1.1 \mathrm{ppt}$, respectively, which were close to the values found in the natural environment at the time of the collection of the fish.

\section{Experimental diets}

A reference diet was used, with $325 \mathrm{~g} \mathrm{~kg}^{-1}$ crude protein and 3,692 $\mathrm{Kcal} \mathrm{kg}^{-1}$ (Table 1) and $1.0 \mathrm{~g} \mathrm{~kg}^{-1}$ chromium oxide $\left(\mathrm{Cr}_{2} \mathrm{O}_{3}\right)$ as inert digestibility marker, based on the information for the pacu (Piaractus mesopotamicus) and the diet was formulated using the computer program SUPER CRAC ${ }^{\circledR}$. The test diets were prepared using a mixture of $70 \%$ of the reference diet with $30 \%$ of the ingredient to be tested. In the preparation of the feed, the ingredients were milled using a knife-type mill, passed through a matrix of $0.5 \mathrm{~mm}$, and subsequently homogenized according to the formulation of each diet.

Table 1. Composition of the reference diet.

\begin{tabular}{lr}
\hline Ingredients & $\left(\mathrm{g} \mathrm{Kg}^{-1}\right)$ \\
\hline Soybean meal 45\% & 320.00 \\
Corn meal & 238.60 \\
Fish meal 55\% & 220.00 \\
Corn gluten meal 22\% & 130.00 \\
Wheat bran & 75.20 \\
Vitamin-mineral premix ${ }^{1}$ & 10.00 \\
Ordinary salt & 5.00 \\
B H T $^{2}$ & 0.20 \\
Chromium Oxide III & 1.00 \\
\hline \multicolumn{2}{c}{ Values analyzed $\left.^{-1}\right)$} \\
\hline Gross energy $\left(\mathrm{Kcal} \mathrm{kg}^{-1}\right)$ & 3,692 \\
Crude protein $\left(\mathrm{g} \mathrm{Kg}^{-1}\right)$ & 325.00 \\
Crude fiber $\left(\mathrm{g} \mathrm{Kg}^{-1}\right)$ & 42.10 \\
Fat (g Kg-1 & 56.40 \\
\hline
\end{tabular}

${ }^{1}$ Vitamin-mineral premix $\left(\mathrm{Kg}^{-1}\right.$ composition of the product): vit. $\mathrm{A}=6,000,000 \mathrm{UI}$; vit. $\mathrm{D} 3=2,250,000 \mathrm{UI}$; vit. $\mathrm{E}=75,000$ $\mathrm{mg}$; vit. $\mathrm{K} 3=3,000 \mathrm{mg}$; vit. thiamine $=5,000 \mathrm{mg}$; riboflavin $=$ $10,000 \mathrm{mg}$; vit. pyridoxine $=8,000 \mathrm{mg}$; biotin $=2,000 \mathrm{mg}$; vit. C $=192,500 \mathrm{mg}$; niacin $=30,000 \mathrm{mg}$; folic acid = 3,000 mg; $\mathrm{Fe}=$ $100,000 \mathrm{mg} ; \mathrm{Cu}=600 \mathrm{mg} ; \mathrm{Mn}=60,000 \mathrm{mg} ; \mathrm{Zn}=150,000 \mathrm{mg}$; $\mathrm{I}=4,500 \mathrm{mg} ; \mathrm{Cu}=15,000 \mathrm{mg} ; \mathrm{Co}=2,000 \mathrm{mg} ; \mathrm{Se}=400 \mathrm{mg}$.

${ }^{2} \mathrm{BHT}=$ Butyl hydroxy toluene.

The diets were processed using a meat grinder with a reverser equipped with a $2-\mathrm{mm}$ matrix. Prior to this, the mixture was wetted using water at $40^{\circ} \mathrm{C}$ and the granules of the diets were dried in an oven $\left(55^{\circ} \mathrm{C}\right)$ with forced ventilation for $24 \mathrm{~h}$ and were then ground to suitable particle size to fit the size of the mouth of the fish, thus facilitating ingestion.

The apparent digestibility coefficients of dry matter (ADCDM), crude protein (ADCCP), gross energy (ADCGE) and amino acids (CDAAA) of the reference diet and of the seven ingredients used were evaluated: three protein sources (soybean meal, corn gluten meal and fish meal) and four 
energy sources (corn meal, wheat bran, rice bran and corn starch). Each ingredient was tested three times. Each repetition was also represented by a pool of feces that was collected in the same digestibility aquarium for each treatment, so that each group of 10 fish received the same diet throughout the experiment.

\section{Digestibility trials}

The fish were fed five times a day (8:00, 10:00, 12:00, 14:00 and 16:00) until apparent satiety, and each repetition was separated by a period of seven days, with the fecal collection occurring in the last five days. At the end of the day, after the last feeding, the digestibility aquaria were siphoned and $20 \%$ of the water was exchanged, to remove what remained of the diets. At 7:00 the next morning, the collectors of the aquaria were decoupled, to remove the water excess and the collected material was deposited in aluminum containers, which were then identified and deposited in an oven with forced circulation at $55^{\circ} \mathrm{C}$ for $24 \mathrm{~h}$. Then, the fish scales present in the feces were removed by a sieve with a mesh of $1 \mathrm{~mm}$ and a caliper. The dried samples were stored in plastic containers and kept in the refrigerator $\left(4^{\circ} \mathrm{C}\right)$, to determine the chemical composition. For each tested diet, the fish were allowed a period of one week to adapt to the new diet, followed by five days of fecal collection and two days of rest.

The analysis of matter (DM) and gross energy (GE) were performed at the Laboratory of Food and Fish Nutrition (AQUANUT-UESC) and the crude protein (CP) tests were performed according to AOAC (2000) methodology. Amino acid (AA) analysis was performed by the CBO Laboratory Analysis (Campinas/SP) according to the methodology described by White et al. (1986). The apparent digestibility coefficients (ADC) of the diets were calculated (DE SILVA, 1989; BUREAU et al., 2002) using the following formula:

$$
\begin{gathered}
\operatorname{ADC}(\%)=100-\left(\frac{\% \mathrm{Cr}_{2} \mathrm{O}_{3} \text { diet }}{\% \mathrm{Cr}_{2} \mathrm{O}_{3} \text { feces }}\right) \times\left(\frac{\% \text { nutrients or gross energy feces }}{\% \text { nutrients or gross energy diet }}\right) \\
\mathrm{ADCn}=\frac{\mathrm{ADCDT}-\mathrm{ADCDR} \times \mathrm{Y}}{\mathrm{ADCDT} \times \mathrm{Z}}
\end{gathered}
$$

where the $\% \mathrm{Cr}_{2} \mathrm{O}_{3}$ diet is the percentage of chromium oxide in the diet; and $\% \mathrm{Cr}_{2} \mathrm{O}_{3}$ feces is the percentage of chromium oxide in the feces; $\mathrm{ADC}_{\mathrm{n}}$, is the apparent digestibility coefficient of nutrients or energy; $\mathrm{ADC}_{\mathrm{DT}}$ is the apparent digestibility coefficient of nutrients or energy in the diet tested; $\mathrm{ADC}_{\mathrm{DR}}$ is the apparent digestibility coefficient of nutrients or energy in the reference $\operatorname{diet}$; $\mathrm{Y}=$ the proportion of the reference diet; and $\mathrm{Z}=$ the ratio of the test diet.

\section{Statistical analysis}

The data obtained were submitted to a variance analysis and the differences between the means, when checked, were submitted to the $5 \%$ probability Scott-Knott test, using $\mathrm{R}$ Core Team software (2011).

\section{Results and Discussion}

Apparent digestibility coefficients of dry matter (ADCDM)

Among the analyzed ingredients, soybean meal showed the best ADCDM value $(p<0.05)$, exceeding $65 \%$, followed by corn meal, fish meal, corn starch, rice bran and corn gluten meal (Table 2). 
Table 2. Mean values of apparent digestibility of dry matter (DM), crude protein (CP) and gross energy (GE) by juvenile silver mojarra.

\begin{tabular}{lccc}
\hline \multirow{2}{*}{ Ingredients } & \multicolumn{3}{c}{ Coefficients of Apparent digestibility (\%) } \\
\cline { 2 - 4 } & DM & CP & GE \\
\hline Fish meal 55\% & $49.60^{\mathrm{c}}$ & $92.97^{\mathrm{a}}$ & $51.85^{\mathrm{b}}$ \\
Soybean meal 45\% & $67.45^{\mathrm{a}}$ & $95.16^{\mathrm{a}}$ & $65.23^{\mathrm{a}}$ \\
Corn meal & $56.06^{\mathrm{b}}$ & $91.90^{\mathrm{a}}$ & $60.31^{\mathrm{a}}$ \\
Corn gluten meal 22\% & $40.06^{\mathrm{f}}$ & $85.08^{\mathrm{b}}$ & $37.88^{\mathrm{c}}$ \\
Wheat bran & $32.98^{\mathrm{g}}$ & $79.08^{\mathrm{c}}$ & $33.60^{\mathrm{c}}$ \\
Rice bran & $44.64^{\mathrm{e}}$ & $83.13^{\mathrm{b}}$ & $45.86^{\mathrm{c}}$ \\
Corn starch & $47.29^{\mathrm{d}}$ & $85.10^{\mathrm{b}}$ & $39.75^{\mathrm{c}}$ \\
\hline Coefficient of variation (\%) & 2.05 & 2.89 & 10.91 \\
\hline
\end{tabular}

Means followed by different letters in the columns differ at the level of $5 \%$ probability by the Scott-Knott test $(P<0.05)$.

The digestibility of dry matter results were similar to those observed by Hussain et al. (2011), who evaluated the digestibility of diets with different protein sources of animal origin by recently hatched rohu (Labeo rohita), with eating habits similar to the silver mojarra, and found a value of $50.15 \%$ for fish meal. Similarly, Altan and Korkut (2011) evaluated the digestibility of diets with different levels of plant-derived ingredients on a marine species, European seabass (Dicentrarchus labrax L.), and observed values of ADCDM between $49.63 \%$ and $57.19 \%$ for corn gluten meal, corn meal and soybean meal.

However, higher values than those mentioned above were found by McCoogun and Reigh (1996) for fish meal, corn meal and wheat bran for juvenile red drum (Sciaenopolis ocellatus) and by Zhou et al. (2004), who studied fish meal, soybean meal and corn gluten bran feed in black salmon (Rachycentrun cabadum) (Table 3).
Different factors can affect the digestibility of dry matter of the ingredients, including the type of raw material used, the preparation of the diet and the studied species. High levels of ash can be found in fish meal produced by the fish filleting industry, which uses fish and their byproducts, which can lead to a poor digestibility of the feed (BEDFORD, 1995; ASP, 1996). Although no set requirement was defined in terms of crude fiber by silver mojarra, it is known that the high dry fiber levels of some vegetable-based diets, such as wheat and rice bran, can accelerate the pass rate of the food through the digestive tract, thereby reducing the digestion and absorption process of nutrients, as reported by Lanna et al. (2004), who evaluated the levels of fiber in the diet of the Nile tilapia (Oreochromis niloticus), and reported that diets with high levels of fiber show reduced food fiber digestibility coefficients. 
Table 3. Comparison of the values of coefficients of apparent digestibility (CAD) of dry matter (DM), crude protein (CP) and gross energy (GE) of the ingredients evaluated, with those found in the literature used.

\begin{tabular}{|c|c|c|c|c|c|}
\hline \multirow{2}{*}{ Ingredients } & \multicolumn{3}{|c|}{ CAD (\%) } & \multirow{2}{*}{ Marine species } & \multirow{2}{*}{ Reference } \\
\hline & DM & $\mathrm{CP}$ & GE & & \\
\hline \multirow{6}{*}{ Fish meal } & 49.60 & 92.97 & 51.85 & Silver mojarra (Diapterus Rhombeus) & Data obtained \\
\hline & 76.79 & 95.87 & 60.14 & Red drum (Sciaenopolis ocellatus) & McCoogun and Reigh (1996) \\
\hline & 87.56 & 96.27 & 95.46 & Black salmon (Rachycentrun cabadum) & Zhou et al. (2004) \\
\hline & - & 93.50 & 87.90 & European seabass (Dicentrachus l.) & Davies et al. (2009) \\
\hline & - & 87.50 & 84.90 & Golden Fish (Sparus aurata) & Davies et al. (2009) \\
\hline & - & 82.80 & 74.50 & Halibut (Scophthalmus maximus) & Davies et al. (2009) \\
\hline \multirow{3}{*}{$\begin{array}{c}\text { Soybean } \\
\text { meal }\end{array}$} & 67.45 & 95.16 & 65.23 & Silver mojarra (Diapterur rhombeus) & Data obtained \\
\hline & 74.60 & 88.30 & 77.90 & Black salmon (Rachycentrun cabadum) & Zhou et al. (2004) \\
\hline & 78.74 & 90.96 & 82.66 & seabass (Centropomus parallelus) & Barroso et al. (2002) \\
\hline \multirow{3}{*}{ Corn meal } & 56.06 & 91.90 & 60.31 & Silver mojarra (Diapterus rhombeus) & Data obtained \\
\hline & 58.10 & 81.56 & 55.96 & Red drum (Sciaenopolis ocellatus) & McCoogun and Reigh (1996) \\
\hline & 27.48 & 86.74 & 40.67 & Striped bass (M. saxalitis $x$ M. chrysops) & Sullivan and Reigh (1995) \\
\hline \multirow{2}{*}{$\begin{array}{c}\text { Corn gluten } \\
\text { meal }\end{array}$} & 40.06 & 85.08 & 37.88 & Silver mojarra (Diapterus rhombeus) & Data obtained \\
\hline & 84.58 & 94.42 & 94.23 & Black salmon (Rachycentrun cabadum) & Zhou et al. (2004) \\
\hline \multirow{2}{*}{ Wheat bran } & 32.98 & 79.08 & 33.60 & Silver mojarra (Diapterus rhombeus) & Data obtained \\
\hline & 35.57 & 87.39 & 33.69 & Red drum (Sciaenopolis ocellatus) & McCoogun and Reigh (1996) \\
\hline \multirow{4}{*}{ Rice bran } & 44.64 & 83.03 & 45.86 & Silver mojarra (Diapterus rhombeus) & Data obtained \\
\hline & 17.64 & 77.15 & 11.96 & Red drum (Sciaenopolis ocellatus) & McCoogun and Reigh (1996) \\
\hline & 59.34 & 86.98 & 69.06 & seabass (Centropomus parallelus) & Barroso et al. (2002) \\
\hline & 31.06 & 71.41 & 47.01 & Striped bass (M. saxalitis $x$ M. chrysops) & Sullivan and Reigh (1995) \\
\hline
\end{tabular}

Apparent digestibility coefficients of crude protein (ADCCP)

No significant differences were observed between the digestibility of crude protein of soybean meal, fish meal and corn meal, with values ranging between $91.90 \%$ and $95.16 \%$. Wheat bran had the lowest value among the tested ingredients, below $80 \%$ of ADCCP. This low amount compared to the other evaluated ingredients might be related to the high crude fiber and non-starch polysaccharide content.

Thus, the silver mojarra can digest proteins of both animal and vegetable origin proteins equally well, which is essential for the industry, because animal protein sources are the most expensive ingredients of the diets.

Corn meal showed similar protein digestibility results to those of soybean meal and fish meal. According to Boscolo et al. (2002), although the protein is present in low quantities at the time of preparation, the shredding process of this grain exposes this protein to rapid digestion, which can explain the high levels of protein digestibility found for corn meal protein.

The ADCCP obtained for recently hatched silver mojarra varied from $79.08 \%$ to $95.16 \%$, among the tested ingredients. The lower digestibility coefficient for wheat bran protein, compared to that for the other evaluated ingredients might be related to the high crude fiber and non-starch polysaccharide content. Similar results were also found by Furuya et al. (2001a), who studied the digestibility of some ingredients for Nile tilapia, and found the worst ADCCP values for wheat bran.

The obtained results were higher than those described by Gonçalves and Carneiro (2003) who assessed diets with different ingredients for juvenile painted fish (Pseudoplatystoma coruscans) and found an ADCCP for soybean meal of $67.1 \%$, for 
rice bran of $44.2 \%$ and for corn meal of $64.2 \%$. However, for fish meal, McCoogun and Reigh (1996), Zhou et al. (2004) and Davies et al. (2009) found digestibility values of crude protein greater than $93 \%$ in red drum, black salmon and European seabass, respectively, with values greater than those obtained in this study (Table 4). These results might be related to the food habits of the studied species, since carnivorous species prefer protein sources of animal origin rather than those of vegetable origin, favored by omnivorous species.

\section{Apparent digestibility coefficients of gross energy (ADCGE)}

The ingredients with the highest digestibility by silver mojarra were soybean meal and corn meal, which showed no difference in digestibility. Lower values were found for fish meal, followed by corn gluten meal, rice bran, corn starch and wheat bran, which did not exceed $50 \%$ digestibility.

The ADCGE values found in this study were similar to those obtained by Gonçalves and Carneiro (2003), which were $61.7 \%, 64.9 \%$ and $72.8 \%$ for soybean meal, corn meal and fish meal, respectively, using newly hatched painted fish. One of the differences between the results obtained in this study and those obtained with painted fish is that carnivorous fish do not possess morphological and physiological adaptations that enable them to efficiently use diets with high amounts of vegetable ingredients, and are instead, best adapted to use amino acids and lipids from animal sources. By contrast, omnivores utilize the protein (amino acids) and carbohydrates of plant sources (LUPATSCH et al., 1997; TENGJAROENKUL et al., 2000), thus promoting the use of vegetable sources of these ingredients in feed formulations for growing species of omnivores.

Hussain et al. (2011) studied the digestibility of fish meal in recently hatched Labeo rohita and found an ADCGE of $69.3 \%$, a value that is higher than that found for silver mojarra. Values above $60 \%$ were also found by McCoogun and Reigh (1996), Zhou et al. (2004) and Davies et al. (2009) (Table 4). However, imported fish meal, produced using whole marine fishes, is of superior quality. In Brazil, high-quality fish meal is scarce and is usually produced using fish leftovers from the fish processing industry. This means that the national product is below international quality and contains high levels of ash, rancid lipids and protein degradation (TEIXEIRA et al., 2008).

Zhou et al. (2004) also studied juvenile black salmon (Rachycention canadum), fed with extruded ration and found values of $86.93 \%$ and $94.23 \%$, for the ADCGE of soybean meal and corn gluten meal, respectively, which are higher than those found in this study with silver mojarra. The variation in digestibility values of the ingredients tested might be associated with the processing of the diets; the feed that is transformed into pellets suffers changes in its physical and chemical characteristics to a lesser degree than that which is extruded, especially in terms of strength, pellet stability and nutrient digestibility (BOOTH et al., 2000). According to Drew et al. (2007), the high pressure, humidity and temperature of the extrusion process favors a higher gelatinization of starch and higher release of the nutrients contained within the plant cells to digestion, improving feed efficiency and digestibility;

\section{Apparent digestibility coefficients of amino acids (ADCAA)}

Among the essential amino acids analyzed, the ADC of lysine, methionine and threonine did not statistically vary for fish meal, soybean meal and corn meal, and varied between $92.52 \%$ and $96.90 \%$ (Table 4). However, for ingredients such as wheat bran, rice bran and corn starch, the ADC of these amino acids was less than $91 \%$. Lysine showed the highest ADC for the corn gluten meal, compared to the mean values. 
Table 4. Apparent digestibility coefficient values (\%) for amino acids of the ingredients by juvenile silver mojarra.

\begin{tabular}{|c|c|c|c|c|c|c|c|c|}
\hline Aminoacids & Fish meal & $\begin{array}{c}\text { Soybean } \\
\text { meal }\end{array}$ & $\begin{array}{l}\text { Corn } \\
\text { meal }\end{array}$ & $\begin{array}{c}\text { Corn gluten } \\
\text { meal }\end{array}$ & $\begin{array}{l}\text { Wheat } \\
\text { bran }\end{array}$ & $\begin{array}{l}\text { Rice } \\
\text { bran }\end{array}$ & $\begin{array}{l}\text { Corn } \\
\text { starch }\end{array}$ & $\begin{array}{l}\mathrm{CV} \\
(\%)\end{array}$ \\
\hline \multicolumn{9}{|l|}{ Essential } \\
\hline Arginine & $95.00^{\mathrm{aA}}$ & $95.15^{\mathrm{aA}}$ & $96.47^{\mathrm{aB}}$ & $88.76^{\mathrm{bA}}$ & $85.06^{\mathrm{bB}}$ & $89.51^{\mathrm{bB}}$ & $90.04^{\mathrm{bB}}$ & 2.77 \\
\hline Isoleucine & $91.88^{\mathrm{aB}}$ & $92.20^{\mathrm{aA}}$ & $94.14^{\mathrm{aB}}$ & $79.89^{\mathrm{bA}}$ & $76.90^{\mathrm{bC}}$ & $73.83^{\mathrm{bE}}$ & $82.18^{\mathrm{bC}}$ & 5.24 \\
\hline Leucine & $92.40^{\mathrm{aB}}$ & $93.56^{\mathrm{aA}}$ & $94.20^{\mathrm{aB}}$ & $86.70^{\mathrm{bA}}$ & $78.7^{\mathrm{cC}}$ & $84.15^{\mathrm{bC}}$ & $83.08^{\mathrm{bC}}$ & 3.27 \\
\hline Lysine & $95.38^{\mathrm{aA}}$ & $96.32^{\mathrm{aA}}$ & $96.90^{\mathrm{aA}}$ & $92.74^{\mathrm{aA}}$ & $86.68^{\mathrm{bB}}$ & $90.36^{\mathrm{bB}}$ & $90.62^{\mathrm{bB}}$ & 3.17 \\
\hline Methionine & $92.84^{\mathrm{aB}}$ & $94.21^{\mathrm{aA}}$ & $94.17^{\mathrm{aB}}$ & $86.13^{\mathrm{bA}}$ & $82.37^{\mathrm{bC}}$ & $86.83^{\mathrm{bC}}$ & $86.03^{\mathrm{bC}}$ & 4.05 \\
\hline Phenylalanine & $92.08^{\mathrm{aB}}$ & $93.25^{\mathrm{aA}}$ & $94.72^{\mathrm{aB}}$ & $79.28^{\mathrm{bA}}$ & $79.76^{\mathrm{bC}}$ & $80.77^{\mathrm{bD}}$ & $82.87^{\mathrm{bC}}$ & 6.75 \\
\hline Threonine & $93.30^{\mathrm{aB}}$ & $92.52^{\mathrm{aA}}$ & $93.96^{\mathrm{aB}}$ & $83.94^{\mathrm{bA}}$ & $77.34^{\mathrm{cC}}$ & $82.83^{\mathrm{bD}}$ & $84.37^{\mathrm{bC}}$ & 3.58 \\
\hline Valine & $70.41^{\mathrm{bB}}$ & $75.95^{\mathrm{bA}}$ & $79.49^{\mathrm{bB}}$ & $82.28^{\mathrm{bA}}$ & $91.65^{\mathrm{aC}}$ & $91.90^{\mathrm{aA}}$ & $93.37^{\mathrm{ac}}$ & 5.82 \\
\hline Histidine & $94.19^{\mathrm{aA}}$ & $94.88^{\mathrm{aA}}$ & $95.41^{\mathrm{aB}}$ & $89.49^{\mathrm{bA}}$ & $82.27^{\mathrm{cC}}$ & $87.26^{\mathrm{bC}}$ & $86.77^{\mathrm{bC}}$ & 2.75 \\
\hline \multicolumn{9}{|l|}{ Non Essential } \\
\hline Alanine & $94.65^{\mathrm{aA}}$ & $93.02^{\mathrm{aA}}$ & $93.60^{\mathrm{aB}}$ & $88.91^{\mathrm{aA}}$ & $80.01^{\mathrm{bC}}$ & $84.62^{\mathrm{bC}}$ & $84.83^{\mathrm{bC}}$ & 3.04 \\
\hline Aspartic acid & $97.99^{\mathrm{aA}}$ & $98.56^{\mathrm{aA}}$ & $98.77^{\mathrm{aA}}$ & $96.90^{\mathrm{aA}}$ & $93.41^{\mathrm{bA}}$ & $97.71^{\mathrm{aA}}$ & $97.76^{\mathrm{aA}}$ & 1.25 \\
\hline Glycine & $96.31^{\mathrm{aA}}$ & $94.05^{\mathrm{aA}}$ & $93.90^{\mathrm{aB}}$ & $88.20^{\mathrm{bA}}$ & $81.78^{\mathrm{cC}}$ & $90.60^{\mathrm{aB}}$ & $87.31^{\mathrm{bC}}$ & 2.75 \\
\hline Glutamic acid & $96.23^{\mathrm{aA}}$ & $97.39^{\mathrm{aA}}$ & $97.41^{\mathrm{aA}}$ & $94.17^{\mathrm{bA}}$ & $88.08^{\mathrm{cB}}$ & $93.22^{\mathrm{bA}}$ & $93.55^{\mathrm{bB}}$ & 2.24 \\
\hline Cystine & $88.52^{\mathrm{aB}}$ & $86.75^{\mathrm{aA}}$ & $91.72^{\mathrm{aC}}$ & $85.98^{\mathrm{aA}}$ & $78.91^{\mathrm{bC}}$ & $75.44^{\mathrm{bE}}$ & $82.28^{\mathrm{bC}}$ & 5.99 \\
\hline Tyrosine & $91.83^{\mathrm{aB}}$ & $93.38^{\mathrm{aA}}$ & $95.23^{\mathrm{aB}}$ & $76.73^{\mathrm{bA}}$ & $81.73^{\mathrm{bC}}$ & $81.06^{\mathrm{bD}}$ & $85.11^{\mathrm{bC}}$ & 6.89 \\
\hline Proline & $95.08^{\mathrm{aA}}$ & $94.61^{\mathrm{aA}}$ & $94.89^{\mathrm{aB}}$ & $89.09^{\mathrm{bA}}$ & $82.93^{\mathrm{cC}}$ & $90.84^{\mathrm{aB}}$ & $87.17^{\mathrm{bC}}$ & 2.47 \\
\hline Serina & $94.15^{\mathrm{aA}}$ & $94.18^{\mathrm{aA}}$ & $95.17^{\mathrm{aB}}$ & $88.79^{\mathrm{bA}}$ & $80.78^{\mathrm{cC}}$ & $87.67^{\mathrm{bC}}$ & $86.66^{\mathrm{bC}}$ & 2.99 \\
\hline Taurine & $97.98^{\mathrm{aA}}$ & $94.20^{\mathrm{aA}}$ & $95.48^{\mathrm{aC}}$ & $85.71^{\mathrm{bA}}$ & $81.61^{\mathrm{bB}}$ & $94.20^{\mathrm{aA}}$ & $79.50^{\mathrm{bC}}$ & 4.55 \\
\hline
\end{tabular}

Means followed by different letters in the rows (lowercase) and columns (capitals) differ at the level of 5\% probability by the ScottKnott test $(P<0.05)$.

The mean values of the ADC of non-essential amino acids from fish meal, soybean meal and corn meal showed no statistical difference; however, wheat bran, showed the lowest values of apparent digestibility for glycine, glutamic acid, proline and serine, with values between $80.78 \%$ and $88.08 \%$.

Analyzing the essential ADCAA found for the feed, fish meal showed the highest values for lysine, arginine and histidine, followed by the other amino acids. There was no statistical difference between the apparent digestibility of amino acids for soybean meal and corn gluten meal, and for corn meal, lysine showed the highest ADC, exceeding 90\%.

Soybean meal and corn gluten meal showed no significant difference in the ADCAA of nonessential amino acids and fish meal had the lowest values for cysteine and tyrosine, at $92 \%$. Among all tested ingredients, rice bran showed the greatest variation in ADCAA.

Lysine is considered the primary limiting amino acid in fish diets, and has a function in body protein deposition and acts in the formation of collagen (TEIXEIRA et al., 2008). Fish have high levels of lysine in muscle tissue and it is required in large quantities in the diet (FURUYA et al., 2004). The ADC of lysine for corn gluten meal, fish meal and soybean meal was higher than that found by Zhou et al. (2004), Guimarães et al. (2008) and Abimorad et al. (2008), who studied the digestibility of these ingredients in black salmon, Nile tilapia and pacu fish, respectively.

In this study, the results for lysine digestibility corroborate those obtained by Davies et al. (2009), who evaluated the ADC of lysine for fish meal in 
European seabass, golden fish (Sparus aurata) and halibut (Psetta maxima) and found digestibility values of $98.0 \%, 94.3 \%$ and $94.7 \%$, respectively. These values are similar to those found by Zhou et al. (2004) with the same ingredient $(97.5 \%)$ for black salmon. Wheat bran had a low ADC of lysine and therefore, is an ingredient that should be a limited component of formulations, since lysine is an essential amino acid for all stages of the fish life cycle.

Methionine is an essential sulfide amino acid and is of absolute importance for the growth of the organism and normal reproduction, since it cannot be synthesized by the fish. This amino acid is essential for many metabolic processes, such as sulfur supply to cellular components, contributing to the synthesis of choline, creatine, sarcosine and adrenaline in transmethylation processes required for the formation of proteins (ALAM et al., 2000). The ADC of methionine for corn meal, fish meal and soybean meal varied between $92.8 \%$ and $94.2 \%$. These values are higher than those found by Ribeiro et al. (2011), who studied the same ingredients in the Nile tilapia, and found a mean apparent digestibility of methionine between 79.6\% and $91.1 \%$. Ingredients with a high digestibility of methionine as mentioned above should be provided preferably during periods of spawning and reproduction.

Compared to other ingredients usually used in manufacturing diets for fish, the ADC of methionine for corn meal, fish meal and soybean meal were superior to those for wheat bran (74.1\%) (FURUYA et al., 2001b), corn meal (84.6\%) (RIBEIRO et al., 2011) and cottonseed meal (81.5\%) (GUIMARÃES et al., 2008) for the Nile tilapia and wheat bran $(82.8 \%)$ and corn meal $(79.8 \%)$ for the pacu fish (ABIMORAD et al., 2008).

The results of this study agree with those found by Zhou et al. (2004), who studied the ADC of methionine for fish meal $(95.9 \%)$ and soybean meal $(92.1 \%)$ in black salmon, and by Davies et al. (2009), who observed an ADC of methionine for fish meal of $99.6 \%$, for the European seabass of $90.96 \%$, for gold fish of $90.96 \%$ and for halibut of $93.7 \%$. According to Silva et al. (2006), after the amino acids lysine and methionine, threonine is one of the most limiting amino acid for fishes, since in stress situations, it assists in the production of mucin and immunoglobulins used in the covering of the skin.

The digestibility coefficient of threonine for soybean meal, corn gluten meal, corn flour and wheat bran values found in this study were similar to those obtained by Ribeiro et al. $(2011,2012)$ for tilapia, with the ADC of threonine varying between $73.0 \%$ to $90.3 \%$. Although silver mojarra is an omnivorous species, the digestibility coefficient of threonine for fish meal was similar to that reported by Davies et al. (2009) for carnivorous marine species such as turbot, bream and European seabass, with the ADC exceeding $88 \%$.

\section{Conclusion}

Juvenile silver mojarra demonstrated the ability to digest and absorb nutrients and some key amino acids, such as lysine, methionine and threonine, more efficiently from fish meal, soybean meal and corn meal.

\section{Acknowledgements}

We thank the fishermen from Cajaíba, Camamu City (Bahia) who participated in the collection of fish samples. We thank the Coordination for the Improvement of Higher Education Personnel (Capes) (process: 2554/2010) and the National Council for Scientific and Technological Development (CNPq) (process: 562040/2010-2) for their financial support. 


\section{References}

ABIMORAD, E. G.; SQUASSONI, G. H.; CARNEIRO, D. J. Apparent digestibility of protein, energy, and amino acids in some selected feed ingredients for pacu Piaractus mesopotamicus. Aquaculture Nutrition, Oxford, v. 14, n. 4, p. 374-380, 2008.

ALAM, M. D. S.; TESHIMA, S. I.; ISHIKAWA, M.; KOSHIO, S. Methionine requirement of juvenile japanese flounder, Paralichthys olivaceus. Journal of the World Aquaculture Society, New Orleans, v. 31, n. 4, p. 618-626, 2000.

ALTAN, O.; KORKUT, A. Y. Appearent digestibility of plant protein based diets by european sea bass Dicentrarchus labrax L., 1758. Turkish Journal of Fisheries and Aquatic Sciences, Trabzon, v. 11, n. 1, p. 87-92, 2011.

ARAÚJO, F. G.; SANTOS, A. C. A. Distribution and recruitment of mojarras (perciformes, gerreidae) in the continental margin of sepetiba bay, Brazil. Bulletin of Marine Science, Miami, v. 65, n. 2, p. 431-439, 1999.

ASP, N.G. Dietary carbohydrates: classification by chemistry and physiology. Food Chemistry, Amsterdam, v. 57, n. 1, p. 9-14, 1996.

ASSOCIATION OF OFFICIAL ANALYTICAL CHEMISTS - AOAC. Official methods of analysis. $17^{\text {th }}$ ed. AOAC INTERNATIONAL, Gaithersburg, 2000. $1018 \mathrm{p}$.

AYALA-PEREZ, L. A.; GÓMES-MONTES, B. A.; MIRANDA, J. R. Distribución, abundancia y parámetros poblacionales de la mojarra Diapterus rhombeus (Pisces: Gerreidae) en la Laguna de Términos, Campeche, México. Revista de Biologia Tropical, San José, v. 49, n. 2, p. 635-642, 2001.

BARROSO, M. V.; CASTRO, C. J.; AOKI, M.; HELMER, J. L. Valor nutritivo de alguns ingredientes para o robalo (Centropomus parallelus). Revista Brasileira de Zootecnia, Viçosa, MG, v. 31, n. 6, p. 2157 2164, 2002.

BEDFORD, M. R. Mechanism of action and potential environmental benefits from the use of feed enzymes. Animal Feed Science and Technolog, Oxford, v. 53, n. 2, p. 145-155, 1995.

BOOTH, M. A.; ALLAN, G. L.; WARNER-SMITH, R. Effects of grinding, steam conditioning and extrusion of a pratical diet on digestibility and weight gain of silver perch, Bidyanus bidyanus. Aquaculture, Amsterdam, v. 182, n. 3-4, p. 287-299, 2000.
BOSCOLO, W. R.; HAYASHI, C.; MEURER, F. Digestibilidade aparente da energia e nutrientes de alimentos convencionais e alternativos para a tilápia do Nilo (Oreochromis niloticus, L.). Revista Brasileira de Zootecnia, Viçosa, MG, v. 31, n. 2, p. 539-545, 2002.

BUREAU, D. P.; HARRIS, A. M.; CHO, C. Y. Bioenergetics. In: HALVER, J. E.; HARDY, R. (Ed.). Fish nutrition. $3^{\text {th }}$ ed. New York: Elsevier Science, 2002. p. 1-59.

CHAVES, P. T. C.; OTTO, G. Aspectos biológicos de Diapterus rhombeus (Cuvier) (Teleostei, Gerreidae) na Baía de Guaratuba, Paraná, Brasil. Revista Brasileira de Zooologia, Curitiba, v. 15, n. 2, p. 289-295, 1998.

COSTA, M. R.; ALBIERI, R. J.; NEVES, L. M.; SANTOS, A. B. L.; ARAUJO, F. G. Distribution and size of the mojarra Diapterus rhombeus (cuvier) (actinopterygii, gerreidae) in a southeastern brazilian bay. Brazilian Journal of Oceanography, São Paulo, v. 60, n. 2, p. 199-207, 2012.

CYRINO, J. E. P.; BICUDO, A. J. A.; SADO, R. Y.; BORGHESI, R.; DAIRIKI, J. K. A piscicultura e o ambiente - o uso de alimentos ambientalmente corretos em piscicultura. Revista Brasileira de Zootecnia, Viçosa, MG, v. 39, p. 68-87, 2010. Suplemento Especial.

DAVIES, S. J.; GOUVEIA, A.; LAPORTE, J.; WOODGATE, S. L.; NATES, S. Nutrient digestibility profile of premium (category III grade) animal protein by-products for temperate marine fish species (European sea bass, gilthead sea bream and turbot). Aquaculture Research, Oxford, v. 40, n. 15, p. 1759-1769, 2009.

DE SILVA, S. S. Digestibility evaluations of natural and artificial diets. In: (Ed.). Fish nutrition research in Asia. Philippines: Society Special Publication Manila, 1989. p. 36-45.

DREW, M. D.; BORGESON, T. L.; THIESSEN, D. L. A review of processing of feed ingredients to enhance diet digestibility in finfish. Animal Feed Science and Technology, Oxford, v. 138, n. 2, p. 118-136, 2007.

ETCHEVERS, S. L. Contribution to the biology of Diapterus rhombeus (cuvier) (pisces-gerridae), south of margarita island. Bulletin of marine science, Miami, v. 28, n. 2, p. 385-389, 1978.

FURUYA, W. M.; GONÇALVES, G. S.; FURUYA, V. R. B.; HAYASHI, C. Fitase na alimentação da tilápia do Nilo (Oreochromis niloticus), desempenho e digestibilidade. Revista Brasileira de Zootecnia, Viçosa, MG, v. 30, n. 3, p. 924-929, 2001b. 
FURUYA, W. M.; BOTARO, D; MACEDO, R. M. G.; SANTOS, V. G.; SILVA, L. C. R.; SILVA, T. C.; FURUYA, V. R. B.; SALES, P. J. P. Aplicação do conceito de proteína ideal para redução dos níveis de proteína em dietas para tilápia-do-nilo (Oreochromis niloticus). Revista Brasileira de Zootecnia, Viçosa, MG, v. 34, n. 5, p. 1433-1441, 2005.

FURUYA, W. M.; PEZZATO, L. E.; PEZZATO, A. C.; BARROS, M.; MIRANDA, E. C. Coeficientes de digestibilidade e valores de aminoácidos digestíveis de alguns ingredientes para tilápia do Nilo (Oreochromis niloticus). Revista Brasileira de Zootecnia, Viçosa, MG, v. 30, n. 4, p. 1143-1149, 2001a.

FURUYA, W. M.; SILVA, L. C.; NEVES, P. R.; BOTARO, D.; HAYASHI, C.; SAKAGUTI, E. S.; FURUYA, V. R. B. Exigência de metionina + cistina para alevinos de tilápia do Nilo (Oreochromis niloticus). Ciência Rural, Santa Maria, v. 34, n. 6, p. 1933-1937, 2004.

GODDARD, J. S.; MCLEAN, E. Acid-insoluble ash as inert reference material for digestibility studies in tilapia, Oreochromis aureus. Aquaculture, Amsterdam, v. 194, n. 1, p. 93-98, 2001.

GONÇALVES, E. G.; CARNEIRO, D. J. Coeficientes de digestibilidade aparente da proteína e energia de alguns ingredientes utilizados em dietas para o pintado (Pseudoplatystoma coruscans). Revista Brasileira de Zootecnia, Viçosa, MG, v. 32, n. 4, p. 779-786, 2003.

GUIMARÃES, I. G.; PEZZATO, L. E.; BARROS, M. M. Amino acid availability and protein digestibility of several protein sources for Nile tilapia, Oreochromis niloticus. Aquaculture Nutrition, Oxford, v. 14, n. 5, p. 396-404, 2008.

HUSSAIN, S. M.; AFZAL, M.; SALIM, M.; JAVID, A.; KHICHI, T. A. A.; HUSSAIN, M.; RAZA, S. A. Apparent digestibility of fish meal, blood meal and meat meal for Labeo rohita fingerlings. Journal Animal and Plant Science, Lahore, v. 21, n. 4, p. 807811, 2011.

LANNA, E. A. T.; PEZZATO, L. E.; CECON, P. R.; FURUYA, W. M.; BOMFIM, M. A. D. Digestibilidade aparente e trânsito gastrintestinal em tilápia-do-nilo (Oreochromis niloticus), em função da fibra bruta da dieta. Revista Brasileira de Zootecnia, Viçosa, MG, v. 33, n. 6, p. 2186-2192, 2004.

LUPATSCH, I.; KISSIL, G. W.; SKLAN, D.; PFEFFER, E. Apparent digestibility coefficients of feed ingredients and their predictability in compound diets for gilthead seabream Sparus aurata L. Aquaculture Nutrition, Oxford, v. 3, n. 2, p. 81-89, 1997.
MCCOOGUN, B. B.; REIGH, R. C.Apparent digestibility of selected ingredients in red drum (Sciaenops ocellatus) diets. Aquaculture, Amsterdam, v. 141, n. 3, p. 233-244, 1996.

NATIONAL RESEARCH COUNCIL - NRC. Nutrient requirements of fish and shrimp. Washington: National Academic Press, 2011. 376 p.

R CORE TEAM - R: a language and environment for statistical computing. Vienna, the $\mathrm{R}$ Foundation for Statistical Computing, 2011. Available at: <http:// www.R-project.org/>. Accessed at: 10 ago. 2014.

RIBEIRO, F. B.; LANNA, E. A.; TEIXEIRA, B.; MARCOS, A. D.; DONZELE, J. L.; QUADROS, M.; CUNHA, P. S.; TAKISHITA L. S.; VIANNA, R. A. Apparent and true digestibility of protein and amino acid in feedstuffs used in Nile Tilapia feed as determined by the technique of dissection. Revista Brasileira de Zootecnia, Viçosa, MG, v. 41, n. 5, p. 1075-1081, 2012.

RIBEIRO, F. B.; LANNA, E. A. T.; BOMFIM, M. A. D.; DONZELE, J. L.; QUADROS, M.; CUNHA, P. S. L. True and apparent digestibility of protein and amino acids of feed in Nile tilapia. Revista Brasileira de Zootecnia, Viçosa, MG, v. 40, n. 5, p. 939-946, 2011.

SILVA, L. C. R.; FURUYA, W. M.; SANTOS, L. D.; SANTOS, V. G.; SILVA, T. S. C.; SAlES, P. J. P. Níveis de teonina em rações para tilápia-do-nilo. Revista Brasileira de Zootecnia, Viçosa, MG, v. 35, n. 4, p. 12581264, 2006.

SILVA, J. S.; ESPÓSITO, T. S.; MARCUSCHI, M.; RIBEIRO, K.; CAVALli, R. O.; OLIVEIRA, V.; BEZERRA, R. S. Purification and partial characterisation of a trypsin from the processing waste of the silver mojarra (Diapterus rhombeus). Food Chemistry, Reading, v. 129, n. 3, p. 777-782, 2011.

SULLIVAN, J. A.; REIGH, R. C. Apparent digestibility of selected feedstuffs in diets for hybrid striped bass (Morone saxatilis female X Morone chrysops male). Aquaculture, Amsterdam, v. 138, n. 1-4, p. 313-322, 1995.

TEIXEIRA, E. A.; CREPALDI, D. V.; FARIA, P. M. C.; RIBEIRO, L. P.; MELO, D. C.; EULER, A. C. C. Composição corporal e exigências nutricionais de aminoácidos para alevinos de tilápia ("Oreochromis" sp). Revista Brasileira de Saúde e Produção Animal, Salvador, v. 9, n. 2, p. 239-246, 2008.

TENGJAROENKUL, B.; SMITH, B. J.; CACECI, T.; SMITH, S. A. Distribution of intestinal enzyme activities along the intestinal tract of cultured Nile tilapia, Oreochromis niloticus L. Aquaculture, Amsterdam, v. 182, n. 3-4, p. 317-327, 2000. 
WHITE J. A., HART R. J., FRY J. C. An evaluation of the waters pico-tag system for the amino-acid-analysis of food materials. Journal of Automatic Chemistry, Cairo, v. 8, n. 4, p. 170-177, 1986.
ZHOU, Q. C.; TAN, B. P.; MAI, K. S.; LIUB, Y. J. Apparent digestibility of selected feed ingredients for juvenile cobia, Rachycention canadum. Aquaculture, Amsterdam, v. 241, n. 1-4, p. 441-451, 2004. 